\section{Elevated Histidine Decarboxylase Activity in the Kidney of the Pregnant Mouse}

It has been found in this laboratory that the histamineforming capacity is increased in certain kinds of normal and malignant rapid tissue growth ${ }^{\mathbf{1}} \mathbf{4}$. Rat foetuses, particularly, exhibit very high levels of histidine decarboxylase activity.

The present results in mice reveal a new relationship between histamine metabolism and pregnancy. Adult mice weighing about $30 \mathrm{~g}$ were killed by decapitation and the kidenys examined for histidine decarboxylase activity by procedures developed by SCHAYER et al. ${ }^{5}$ and described in detail by WHITE ${ }^{6}$. The results are summarized in the Table in which for comparison values from some of the richest known sources of mammalian histidine decarboxylase are included.

From the Table it is seen, first, that in the kidney of the non-pregnant female the enzyme level is about twenty times higher than in that of the male. Further, and most striking, in pregnancy the kidney enzyme level is elevated to about fifty times the non-pregnant values. This activation during pregnancy can hardly be due to differences in endogenous amounts of the coenzyme pyridoxal5-phosphate, because addition of this compound to nonpregnant kidney mince during incubation with ${ }^{14} \mathrm{C}$-histidine did not cause a significant increase in the rate of formation of ${ }^{14} \mathrm{C}$-histamine.

The physiological significance of the increased histamine forming capacity in the mouse kidney during pregnancy is open to speculation. SCHAYER ${ }^{7}$ demonstrated the existence of at least two varieties of mammalian histidine decarboxylase. It remains to characterize more specifically the nature of the female mouse kidney enzyme and to see to what extent the enzyme and its increase during pregnancy is species specific.

Zusammenfassung. Die Fähigkeit, ${ }^{14} \mathrm{C}$-Histamin aus ${ }^{14} \mathrm{C}$-Histidin zu bilden, steigt in der Niere der schwangeren Maus enorm an. Dieses Organ ist deshalb eine der reichsten Quellen von tierischer Histidindecarboxylase.

\section{Experimental Hypertension Elicited by Injections of Methyl Cellulose ${ }^{1}$}

It has been shown that when various animal species are injected with methyl cellulose, storage cell macrophages and vascular endothelial cells incorporate the material thereby being converted into 'foam cells' ${ }^{2-4}$, resembling the intravascular lipid-filled foam cells which occur in certain forms of human cardiovascular ${ }^{5}$ and renal ${ }^{6}$ disease. Kidney glomeruli are transformed into structures which have been likened to 'grape clusters' because of the marked and extensive endothelial swelling. Recent examination, in our laboratory, of histological material from rats which had been the recipients of hormone solutions containing methyl cellulose as a suspending agent, revealed that the glomerular capillaries were so occluded by endothelial swelling as to severely curtail the circulation of blood through them. Because of the relationship between 'renal ischemia' and hypertension ${ }^{7,8}$ it seemed worthwhile to investigate the effect which such restriction of intraglomerular circulation might have on the blood pressure.

Method. 20 immature female rats of the Holtzman strain weighing $70-90 \mathrm{~g}$ were unilaterally nephrectomized and placed on a $1 \% \mathrm{NaCl}$ intake, procedures which are known to facilitate induction of hormonal hypertension ${ }^{\circ}$. Ten of
The histidine decarboxylase activity of kidneys in male, pregnant and non-pregnant mice. Each figure represents the observation from one mouse. For comparison the activity of rat gastric mucosa and rat foetal liver are shown.

\begin{tabular}{llr}
\hline \multirow{2}{*}{ Species } & Tissue & Histamine formed $(\mathrm{ng} / \mathrm{g} / 3 \mathrm{~h})$ \\
\hline \multirow{2}{*}{ Mouse } & male kidney & 4 \\
& & 8 \\
& & 58 \\
Mouse & female kidney, non-pregnant & 120 \\
& & 310 \\
& & 390 \\
& & 660 \\
Mouse & female kidney, pregnant & 20800 \\
& & 26500 \\
& & 32300 \\
& & 38900 \\
Rat & gastric mucosa & 43400 \\
& & 1010 \\
& & 1340 \\
Rat & foetal liver & 1430 \\
& & 1540 \\
& & 21400 \\
& & 23300 \\
& & 37000 \\
& & 54200 \\
& &
\end{tabular}

Elsa Rosengren and Claudia Steinhardt

Institute of Physiology, University of Lund (Sweden), A ugust 10, 1961.

1 G. Kahlson, E. Rosengren, H. Westling, and T. White, J. Physiol. 144, 337 (1958).

2 G. Kahlson, Lancet $1,67(1960)$

3 R. HÅkansson, Exper. 17, 402 (1961).

4 G. Kahlson, E. Rosengren, and C. Steinhardt, to be published.

5 R. W. Schayer, K. J. Davis, and R. L. Smiley, Amer. J. Physiol. $182,54(1955)$

6 T. White, J. Physiol. 149, 34 (1959).

? R. W. Schayer, Amer. J. Physiol. 189, 533 (1957). them received daily subcutaneous injections of a methyl cellulose solution which ranged between $1 \%$ and $0.25 \%$ concentration. Those which survived the full period of treatment received a total of $106 \mathrm{mg}$ of the polysaccharide. The remaining ten received no injections. Blood pressures were measured periodically on unanesthetized animals by a tail-plethysmograph. The experiment was concluded on the 32 nd day, surviving animals being killed with ether. Organs and tissues from them and those which died intercurrently were taken for weight and microscopic examination.

1 This study was supported by grants $\mathrm{H}-2703$ and $\mathrm{H}-4327$ from the United States Public Health Service.

2 W. C. Hueper, Arch. Path. 33, 1 (1942).

3 J. G. Palmer, E. J. Eichwald, G. E. Cartwright, and M. M. Wintrobe, Blood $8,72(1953)$.

4 T. В. Thон, J. Path. Bact. 81, 33 (1961).

5 J.E. EDwards, An Atlas of Acquired Diseases of the Heart and Great Vessels (W. B. Saunders Co., Philadelphia and London 1961), p. 782 .

6 A. C. Allen, The Kidney: Medical and Surgical Diseases (Grune and Stratton, New York 1951), p. 155.

7 H. Goldblatt, Ann. int. Med. 11,69 (1937).

8 I. H. PAGE, J. Amer. Med, Assoc. 113, 2046 (1989)

$\checkmark$ H. Selye and I. Pentz, Canad. Med. Assoe. J. 49, 264 (1943). 